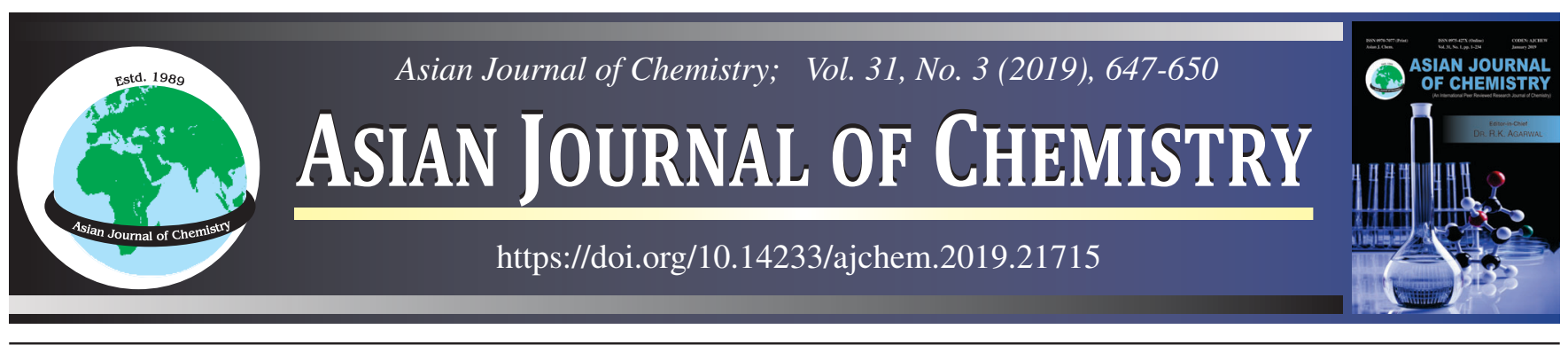

\title{
Effect of Extraction Time and Solvent Power on Phytochemical Screening and Antioxidant Activity of Momordica charantia L. Fruit Extracts
}

\author{
Rayees Ahmad Malik ${ }^{1, *}$, Mabroukah Massuod SaAd ${ }^{1}$ and Surabhi Tiwari ${ }^{2}$
}

${ }^{1}$ Department of Chemistry, Faculty of Science, Sam Higginbottom University of Agriculture, Technology \& Sciences, Allahabad-211007, India ${ }^{2}$ Pharmacognosy and Ethnopharmacology Division CSIR-NBRI, Lucknow-226001, India

*Corresponding author: E-mail: malikraqeeb123@gmail.com

Received: 19 September 2018;

Accepted: 29 November 2018;

Published online: 31 January 2019;

AJC-19262

\begin{abstract}
This work reports the analysis of phytochemical screening and antioxidant activity of Momordica charantia L. fruit extracts at different extraction conditions. The standard procedures are achieved by ferric reducing antioxidant, nitric oxide scavenging assay methods. Extraction under different maceration periods viz. 6, 12, 24 and $48 \mathrm{~h}$ organic solvent especially ethanol was found more effective followed by water extract, acetone and ethyl acetate. The maximum number of phytochemicals were observed at $12 \mathrm{~h}$ followed by $6 \mathrm{~h}$. Hence, the medium time duration influences the extraction of phytochemicals at $12,6 \mathrm{~h}$ rather than 24 and $48 \mathrm{~h}$. The ferric reducing antioxidant activity was observed maximum at $12 \mathrm{~h}(0.156 \pm 0.012,79.31 \%)$ followed by $6 \mathrm{~h}(0.149 \pm 0.022,71.26 \%), 24 \mathrm{~h}(0.143 \pm 0.032,64.36$ $\%)$ and $48 \mathrm{~h}(0.139 \pm 0.023,59.77 \%)$ in ethanolic extract. Similarly the nitric oxide scavenging activity was observed maximum at $12 \mathrm{~h}$ $(0.093 \pm 0.023,76.53 \%)$ followed by $6 \mathrm{~h}(0.113 \pm 0.043,71.17 \%), 24 \mathrm{~h}(0.134 \pm 0.031,65.81 \%)$ and $48 \mathrm{~h}(0.161 \pm 0.053,58.92 \%)$ in ethanolic extract followed by aqueous, acetone, ethyl acetate, petroleum ether and hexane extracts at $12 \mathrm{~h}$ with respect to standard (ascorbic acid). The results show that the ethanol is more effective for extraction of phytochemicals followed by water extract. The maximum number of phytochemicals are obtained at medium time duration $(12 \mathrm{~h})$ in ethanolic extract. Hence demonstrates that fruit extracts are important sources of natural antioxidant agents.
\end{abstract}

Keywords: Momordica charantia L., Antioxidant activity, Organic solvents.

\section{INTRODUCTION}

A wide variety of phytochemicals are produced by plantssecondary metabolites includes alkaloids, tannins, flavonoids, saponins and glycosides [1]. The similar studies are done with water extract, $70 \%$ ethanol extract and fraction of ethyl acetate were not significantly different, but significantly different with $n$-hexane and ethanol fractions [2]. Phytochemicals such as vitamins, terpenoids, phenolic acids, tannins, flavonoids and other metabolites are rich source of antioxidant activity. The phytochemicals with adequate antibacterial were used for the treatment of bacterial infections. The screening of plant extract for antibacterial activity are beneficial for humans and plants diseases [3]. Phenolic compounds (secondary metabolites) are essential for growth and reproduction of plants. They are known as hydrophilic antioxidants and are produced for defending injured plants against pathogens. Free radicals are known for cause of various chronic and degenerative diseases [4]. The oxygen radicals are correlated with cellular and metabolic injury, accelerated aging, cancer, cardiovascular disease, neurodegenerative disease and inflammation [5]. However human body has natural defense system against free radical or oxygen radical but the natural defense system is not sufficient to deal with the amount of free radical or oxygen radical produced under certain conditions. Thus high intake of food antioxidants is essential for decreasing the induction of disorders [6]. The experimental results show the activity is due to several secondary metabolites especially, e.g. phenolic compounds, terpenes, alkaloids and organic sulfur compounds [7]. The scientific evaluation of plant extracts showed potential therapeutic benefit in diabetes and obesity related metabolic dysfunction in animals and clinical studies [8]. Plants of this family have many medicinal and nutritional benefits [9]. Phytochemicals are known to possess antioxidant [10]. Momordica charantia L.

This is an open access journal, and articles are distributed under the terms of the Creative Commons Attribution-NonCommercial-ShareAlike 4.0 (CC BY-NC-SA 4.0) International License which allows readers to freely read, download, copy, distribute, print, search, or link to the full texts of its articles and to use them for any other lawful non-commercial purpose as long as the original source is duly acknowledged. 
belongs to the family of Cucurbitaceae. There are several nutritional and medicinal benefits of this bitter vegetable. Bioactive compounds have great antioxidant potential such as reducing and scavenging of free radicals. Synthetic antioxidants are commonly used in foods but they cause side effects and are carcinogenic. Thus, there has been an upsurge of interest in naturally-occurring antioxidant compounds via suitable extraction conditions.

\section{EXPERIMENTAL}

Momordica charantia L. the experimental fruit was collected from Allahabad, (Uttar Pradesh), India

\section{Preparation of extracts under different extraction conditions}

Variation of time: Powered $100 \mathrm{~g}$ of dry plant material was extracted with $1 \mathrm{~L}$ of various solvents (hexane, petroleum ether, ethyl acetate, acetone, ethanol and water extract) at ratio of $1: 10(\mathrm{w} / \mathrm{v})$ solid to solvent for different maceration periods ( $6 \mathrm{~h}, 12 \mathrm{~h}, 24 \mathrm{~h}$ and $48 \mathrm{~h})$. The extraction was carried out at room temperature with agitation at $150 \mathrm{rpm}$. After the respective maceration periods, the soaked powder-solvent mixtures were filtered through a Whatman filter paper, concentrated to $1 \mathrm{~mL}$ with a rotary evaporator at $40-60{ }^{\circ} \mathrm{C}$ and then stored at $20{ }^{\circ} \mathrm{C}$.

Phytochemical screening of the extracts: The methods described for phytochemical screening of bioactive compounds $[11,12]$.

\section{in vitro Antioxidant activity of Momordica charantia $\mathrm{L}$. fruit in different solvent extracts}

Ferric reducing antioxidant power assay: The method described to carry out ferric reducing antioxidant power assay [13].

Nitric oxide scavenging activity assay: Nitric oxide scavenging activity assay was carried out by the method described [14].
Statistical analysis: Results were expressed as mean \pm S.D. Linear regressions analysis was carried out for standards to calculate the contents.

The percent increase in reducing power was calculated using the following equation:

$$
\text { Reducing power }(\%)=\frac{\mathrm{A}_{\text {test sample }}-\mathrm{B}_{\text {blank }}}{\mathrm{B}_{\text {blank }}} \times 100
$$

The antioxidant nitric oxide scavenging activity was calculated using the following equation:

Nitric oxide scavenging activity $(\%)=\frac{\mathrm{B}_{\text {blank }}-\mathrm{A}_{\text {test sample }}}{\mathrm{B}_{\text {blank }}} \times 100$ where, $\mathrm{A}_{\text {test sample }}$ is absorbance of test solution; $\mathrm{B}_{\text {blank }}$ is absorbance of blank.

\section{RESULTS AND DISCUSSION}

Phytochemical screening of Momordica charantia L. fruit extracts: The essential phytochemicals such as sugars, alkaloids, flavonoids, glycosides, saponins, tannins, terpenoids, anthroquinones, phenols and phlobatannins confirmed their occurrence in majority of the extracts, which had been exposed for extraction by distinctive extraction conditions and solvents. Thus, the analysis showed the occurrence of maximum number of phytochemicals in Momordica charantia L. fruit extracts, which are active medicinal chemical components. The result of the phytochemical screening indicated that the Momordica charantia $\mathrm{L}$. fruit is virtuous resource of phytochemicals.

Phytochemical screening for different extraction time: Phytochemical screening of different solvent fruit extracts of Momordica charantia L. at 6, 12, 24, 48 h. The qualitative phytochemical screening of sugars, alkaloids, flavonoids, glycosides, saponins, tannins, terpenoids, anthroquinones and phenols at $6,12,24,48 \mathrm{~h}$ as shown in Table-1.

TABLE-1

PHYTOCHEMICAL SCREENING OF DIFFERENT SOLVENT FRUIT EXTRACTS OF Momordica charantia L. AT DIFFERENT INTERVAL OF TIME

\begin{tabular}{|c|c|c|c|c|c|c|c|c|c|c|c|c|}
\hline Tests & Hexane & $\begin{array}{l}\text { Pet. } \\
\text { ether }\end{array}$ & $\begin{array}{c}\text { Ethyl } \\
\text { acetate }\end{array}$ & Acetone & Ethanol & $\begin{array}{c}\text { Aqueous } \\
\text { extract }\end{array}$ & Hexane & $\begin{array}{l}\text { Pet. } \\
\text { ether }\end{array}$ & $\begin{array}{c}\text { Ethyl } \\
\text { acetate }\end{array}$ & Acetone & Ethanol & $\begin{array}{c}\text { Aqueous } \\
\text { extract }\end{array}$ \\
\hline & \multicolumn{6}{|c|}{$6 \mathrm{~h}$} & \multicolumn{6}{|c|}{$12 \mathrm{~h}$} \\
\hline Alkaloids & - & - & + & + & + & + & - & - & + & + & + & + \\
\hline Flavonoids & - & - & - & - & - & - & - & - & - & - & - & - \\
\hline Glycosides & - & - & - & + & + & + & - & + & + & + & + & + \\
\hline Saponins & - & - & - & - & + & + & - & - & - & + & + & + \\
\hline Tannins & + & + & + & + & + & + & + & + & + & + & + & + \\
\hline Terpenoids & - & - & - & - & - & - & - & - & - & - & + & - \\
\hline Sugars & + & + & + & + & + & + & + & + & + & + & + & + \\
\hline Anthroquinones & - & - & - & - & - & - & - & - & - & - & - & - \\
\hline \multirow[t]{2}{*}{ Phenols } & - & - & - & - & + & - & - & - & + & + & + & + \\
\hline & \multicolumn{6}{|c|}{$24 \mathrm{~h}$} & \multicolumn{6}{|c|}{$48 \mathrm{~h}$} \\
\hline Alkaloids & - & & - & + & + & + & - & & - & - & + & - \\
\hline Flavonoids & - & - & - & - & + & - & - & - & - & - & - & - \\
\hline Glycosides & + & + & + & + & + & + & + & + & + & + & + & + \\
\hline Saponins & - & - & - & - & - & + & - & - & - & - & - & - \\
\hline Tannins & - & - & - & - & + & - & - & - & - & - & - & - \\
\hline Terpenoids & - & - & - & - & - & - & - & - & - & - & - & - \\
\hline Sugars & + & + & + & + & + & + & + & + & + & + & + & + \\
\hline Anthroquinones & - & - & - & - & - & - & - & - & - & - & - & - \\
\hline Phenols & - & - & - & + & + & + & - & - & + & + & + & + \\
\hline
\end{tabular}

+ Present and - Absent 
The data showed that the qualitative phytochemical screening of phytochemicals upon extraction of different time periods viz. 6, 12, 24, $48 \mathrm{~h}$. The observations shown ethanol is more effective for extraction of phytochemicals followed by water extract, acetone and ethyl acetate. The maximum number of phytochemicals are obtained at $12 \mathrm{~h}$ time duration. The phytochemicals show maximum affinity for extraction towards the solvents such as ethanol, water extract followed by acetone, ethyl acetate, petroleum ether and hexane upon extent of extraction time upto $12 \mathrm{~h}$. The observations showed that prolonged extraction time leads to exposure of more oxygen and thus increase the chances for occurrence of oxidation on compounds and reduces the availability of phytochemicals after 24 and $48 \mathrm{~h}$ time interval. Hence, the medium time duration influences the extraction of phytochemical plant materials rather than 24 and $48 \mathrm{~h}$. Therefore, the extracted phytochemical products confirms that the Momordica charantia $\mathrm{L}$. fruit is a good source of phytonutrients of biological significant. Polarity of the solvent and extraction duration time solely influences the majority of the bioactive compounds obtained from the plant material $[15,16]$. Hence results concluded that the organic solvents especially ethanol is found to be more desirable to extract the phytonutrients [17].

\section{Antioxidant activity of Momordica charantia L. fruit extracts (at conc. $300 \mu \mathrm{g} / \mathrm{mL}$ ) on varied time period}

Ferric reducing antioxidant power (assay): The ferric reducing antioxidant activity was observed maximum at $12 \mathrm{~h}$ $(0.156 \pm 0.012$, followed by $6 \mathrm{~h}(0.149 \pm 0.022), 24 \mathrm{~h}(0.143$ $\pm 0.032)$ and $48 \mathrm{~h}(0.139 \pm 0.023)$ in ethanolic extract followed by extracts of aqueous $(0.145 \pm 0.015,0.143 \pm 0.035,0.137 \pm$
$0.085,0.133 \pm 0.025)$, acetone $(0.139 \pm 0.027,0.138 \pm 0.057$, $0.133 \pm 0.017,0.129 \pm 0.031)$. Similarly with ethyl acetate, petroleum ether and hexane) at 12, 6, 24 and $48 \mathrm{~h}$ with respect to standard (ascorbic acid). From the results (Table-2) it clearly observed that the phytochemicals show more response in organic solvents because of ease of extraction in polar ethanolic solvent. Hence there reducing power can be greatly influenced either by reducing the polarity of solvent and time period during the activity. From the analysis prolonged extraction time leads exposure of more oxygen and increase the chances of oxidation of compounds and reduces the availability of phytochemicals. Therefore the extraction of phytochemicals from Momordica charantia $\mathrm{L}$ using variety of solvents helps the ease of availability of phytochemicals for development of drugs useful for treatment of various diseases particularly due to free radicals [18]. The antioxidant and antimicrobial properties of phenolic natural products from fruits and vegetables are good source for treatment of various diseases [19].

Nitric oxide scavenging activity assay: The nitric oxide scavenging activity was observed maximum at $12 \mathrm{~h}(0.093 \pm$ $0.023)$ followed by $6 \mathrm{~h}(0.113 \pm 0.043), 24 \mathrm{~h}(0.134 \pm 0.031)$ and $48 \mathrm{~h}(0.161 \pm 0.053)$ in ethanolic extract followed by extracts of aqueous $(0.138 \pm 0.041,0.141 \pm 0.011,0.180 \pm$ $0.021,0.190 \pm 0.081)$, acetone $(0.174 \pm 0.018,0.181 \pm 0.013$, $0.199 \pm 0.010,0.161 \pm 0.053)$. Similarly with ethyl acetate, petroleum ether and hexane at 12, 6, 24 and $48 \mathrm{~h}$ with respect to standard (ascorbic acid) (Table-3). The phytochemical screening of leaves and barks of Momordica charantia L. shows the presence of phenols, steroids, tannins, saponins and alkaloids in the hydroalcohol extract. The percentage antioxidant activity

\begin{tabular}{|c|c|c|c|c|}
\hline \multirow{3}{*}{ Extracts } & \multicolumn{3}{|c|}{$\begin{array}{l}\text { TABLE-2 } \\
\text { FERRIC REDUCING ANTIOXIDANT ACTIVITY OF Momordica charantia L. } \\
\text { FRUIT EXTRACTS AT CONC. } 300 \mu \mathrm{g} / \mathrm{mL} \text { AT DIFFERENT TIME PERIOD }\end{array}$} & \\
\hline & \multicolumn{4}{|c|}{ Optical density of Momordica charantia L. extracts } \\
\hline & $6 \mathrm{~h}($ Mean \pm S.D $)$ & $12 \mathrm{~h}($ Mean \pm S.D $)$ & 24 h $($ Mean \pm S.D $)$ & $48 \mathrm{~h}($ Mean \pm S.D $)$ \\
\hline Control & $0.087 \pm 0.021$ & - & - & - \\
\hline Standard & $0.167 \pm 0.062$ & - & - & - \\
\hline Hexane & $0.125 \pm 0.045$ & $0.127 \pm 0.065$ & $0.119 \pm 0.015$ & $0.112 \pm 0.050$ \\
\hline Petroleum ether & $0.127 \pm 0.004$ & $0.129 \pm 0.034$ & $0.124 \pm 0.094$ & $0.116 \pm 0.014$ \\
\hline Ethyl acetate & $0.132 \pm 0.031$ & $0.134 \pm 0.021$ & $0.128 \pm 0.091$ & $0.122 \pm 0.021$ \\
\hline Acetone & $0.138 \pm 0.057$ & $0.139 \pm 0.027$ & $0.133 \pm 0.017$ & $0.129 \pm 0.031$ \\
\hline Ethanol & $0.149 \pm 0.022$ & $0.156 \pm 0.012$ & $0.143 \pm 0.032$ & $0.139 \pm 0.023$ \\
\hline Water extract & $0.143 \pm 0.035$ & $0.145 \pm 0.015$ & $0.137 \pm 0.085$ & $0.133 \pm 0.025$ \\
\hline
\end{tabular}

TABLE-3

ANTIOXIDANT SCAVENGING ACTIVITY OF Momordica charantia L. FRUIT EXTRACTS AT CONC. $300 \mu \mathrm{g} / \mathrm{mL}$ AT DIFFERENT TIME PERIOD

\begin{tabular}{lcccc}
\hline \multirow{2}{*}{ Extracts } & \multicolumn{4}{c}{ Optical density of Momordica charantia L. extracts } \\
\cline { 2 - 5 } & $6 \mathrm{~h}($ Mean \pm S.D) & $12 \mathrm{~h}($ Mean \pm S.D) & $24 \mathrm{~h}($ Mean \pm S.D) & $48 \mathrm{~h}($ Mean \pm S.D) \\
\hline Control & $0.392 \pm 0.021$ & - & - & - \\
Standard & $0.019 \pm 0.062$ & - & - & - \\
Hexane & $0.269 \pm 0.024$ & $0.220 \pm 0.021$ & $0.280 \pm 0.039$ & $0.290 \pm 0.014$ \\
Petroleum ether & $0.232 \pm 0.027$ & $0.201 \pm 0.031$ & $0.254 \pm 0.001$ & $0.269 \pm 0.018$ \\
Ethyl acetate & $0.221 \pm 0.012$ & $0.193 \pm 0.022$ & $0.230 \pm 0.013$ & $0.245 \pm 0.019$ \\
Acetone & $0.181 \pm 0.013$ & $0.174 \pm 0.018$ & $0.199 \pm 0.010$ & $0.209 \pm 0.011$ \\
Ethanol & $0.113 \pm 0.043$ & $0.093 \pm 0.023$ & $0.134 \pm 0.031$ & $0.161 \pm 0.053$ \\
Water extract & $0.141 \pm 0.011$ & $0.138 \pm 0.041$ & $0.180 \pm 0.021$ & $0.190 \pm 0.081$ \\
\hline
\end{tabular}

Absorbance (Mean \pm S.D; $700 \mathrm{~nm})$ 
is high in leaf extract than bark extract and also nitric oxide assay percentage inhibition was compared with the ascorbic acid (standard). It indicates that the plant has the potency of scavenging free radicals and provides new search of natural antioxidants from various medicinal plants used for treating free radical reactions [20].

\section{Conclusion}

The investigations approved under several extraction conditions suggest that the ethanol is more effective for extraction of phytochemicals followed by water extract. The maximum number of phytochemicals are obtained at medium time duration (12 h) in ethanolic extract viz. sugars, alkaloids, flavonoids, glycosides, saponins, tannins, terpenoids, anthroquinones and phenols followed by $6 \mathrm{~h}$ (sugars, alkaloids, glycosides, saponins, tannins and phenols), followed by $24 \mathrm{~h}$ (sugars, alkaloids, glycosides, tannins, terpenoids and phenols), followed by $48 \mathrm{~h}$ (sugars, alkaloids, glycosides and phenols) which confirms that the phytochemicals show maximum affinity for extraction in the polar organic solvents rather than less polar and aqueous solvents.

\section{ACKNOWLEDGEMENTS}

The authors are thankful to Sam Higginbottom University of Agriculture, Technology \& Sciences, Allahabad, India, for providing the facilities to conduct this research work. Thanks to the technical staff for their support.

\section{CONFLICT OF INTEREST}

The authors declare that there is no conflict of interests regarding the publication of this article.

\section{REFERENCES}

1. G. Guerriero, R. Berni, J.A. Muñoz-Sanchez, F. Apone, E.M. AbdelSalam, A.A. Qahtan, A.A. Alatar, C. Cantini, G. Cai, J.-F. Hausman, K.S. Siddiqui, S.M.T. Hernández-Sotomayor and M. Faisal, Genes, 9, 309 (2018);

https://doi.org/10.3390/genes9060309.
2. M.S. Hussain, S. Fareed, S. Ansari, M.A. Rahman, I.Z. Ahmad and M. Saeed, J. Pharm. Bioallied. Sci., 4, 10 (2012); https://doi.org/10.4103/0975-7406.92725.

3. H.S. Gracelin, A.J.D. Britto and P.B. Kumar, Int. J. Pharm. Pharm. Sci., 1, 2013 (2012).

4. M. Valko, D. Leibfritz, J. Moncol, M.T. Cronin, M. Mazur and J. Telser, Int. J. Biochem. Cell Biol., 39, 44 (2007); https://doi.org/10.1016/j.biocel.2006.07.001.

5. J. Kubola and S. Siriamornpun, Food Chem., 110, 881 (2008); https://doi.org/10.1016/j.foodchem.2008.02.076.

6. M. Rajendran, P. Manisankar, R. Gandhidasan and R. Murugesan, J. Agric. Food Chem., 52, 7389 (2004); https://doi.org/10.1021/jf0400718.

7. N.A. Al-Jaber, A.S. Awaad and J.E. Moses, J. Saudi Chem. Soc., 15, 293 (2011); https://doi.org/10.1016/j.jscs.2011.07.004.

8. M.A. Alam, R. Uddin, N. Subhan, M.M. Rahman, P. Jain and H.M. Reza, J. Lipids, 2015, Article ID 496169 (2015); https://doi.org/10.1155/2015/496169.

9. N.S. Gill and M. Bali, Res. J. Phytochem., 5, 70 (2011); https://doi.org/10.3923/rjphyto.2011.70.79.

10. S.K. Wong, Y.Y. Lim and E.W.C. Chan, J. Trop. Forest Sci., 21, 307 (2009).

11. G.E. Trease and W.C. Evans, Pharmacognosy, Bailliere Tindall, London:, edn 11, pp. 45-50 (1989).

12. J.B. Harborne, Phytochemical Methods A Guide to Modern Techniques of Plant Analysis, Chapman \& Hall: London, edn 2, pp. 54-84 (1998).

13. I.F.F. Benzie and J.J. Strain, Anal. Biochem., 239, 70 (1996); https://doi.org/10.1006/abio.1996.0292.

14. S. Kumar, D. Kumar, K. Manjusha Saroha, N. Singh and B. Vashishta, Acta Pharm. Sci., 58, 215 (2008).

15. M. Naczk and F. Shahidi, J. Chromatogr. A, 1054, 95 (2004); https://doi.org/10.1016/S0021-9673(04)01409-8.

16. N. Gunavathy, S. Padmavathy and S.C. Murugavel, J. Int. Acad. Res. Multidiscipl., 2, 212 (2014).

17. D.E. Okwu, Global J. Pure Appl. Sci., 7, 455 (2001); https://doi.org/10.4314/gjpas.v7i3.16293.

18. R.S. Suliman, T. Pohyeen, J. Khan and S. Sultan, The Experiment, 19, 1336 (2014).

19. S. Guettaf, N. Abidli, S. Kariche, L. Bellebcir and H. Bouriche, Der Pharm. Lett., 8, 50 (2016).

20. A. Altemimi, N. Lakhssassi, A. Baharlouei, D.G. Watson and D.A. Lightfoot, Plants, 6, 42 (2017); https://doi.org/10.3390/plants6040042. 